\title{
MONITORING OF BUTYLTIN COMPOUNDS IN THE AQUATIC ENVIRONMENTS OF THE PHILIPPINES
}

\author{
Maricar S. Prudente \\ Science Education Department, De La Salle University, 2401 Taft Avenue \\ Manila 1004 Philippines \\ e-mail:prudentem@dlsu.edu.ph
}

\begin{abstract}
This article provides a comprehensive review of the contamination by Butyltin compounds (BTs) and its possible implications on the marine and coastal environments of the Philippines. Butyltin compounds were detected in mussels from all the sampling locations investigated as part of the monitoring surveys under the Asia-Pacific Mussel Watch (APMW) Program conducted in the late 1990s. BTs were detected in green mussels collected from all the aquaculture sites in the country, suggestive of considerable widespread pollution by BTs in the coastal waters. Among BTs, TBT was detected at all locations at relatively higher concentrations, whereas the concentrations of DBT and MBT were lower. This could be indicative that green mussels have limited ability of metabolize TBT to DBT and MBT. In addition, this result may be suggestive of fresh TBT inputs into the aquatic environments and the presence of recent sources along the coastal waters. Concentrations of OBT in green mussels were reported up to $790 \mathrm{ng} / \mathrm{g}$ wet weight in a site where intensive maritime activities are occurring. Mussels from rural areas contained TBT at lower proportions indicating that TBT usage as antifouling agents is minimal. Tolerable average residue level (TARL) for seafood in the Philippines was estimated at $173 \mathrm{ng} / \mathrm{g}$ wet weight for an average person weighing $60 \mathrm{~kg}$. Concentrations of TBT or the sum of TBT and DBT in some green mussels analysed revealed that some values exceeded TARL level, which could suggest that humans consuming this seafood from areas with high BTs contamination could be at risk from elevated exposure to BTs. Similarly, BTs were detected in all the skipjack tuna collected, suggestive of the widespread contamination even in offshore waters and open seas on a global scale. Skipjack tuna collected from the offshore waters of the Philippines revealed considerable levels (up to $220 \mathrm{ng} / \mathrm{g}$ wet weight), with high percentages of BTs in total tin (ÓSn: inorganic tin + organic tin) in the liver tissues. This finding seems to suggest that the anthropogenic BTs represent the major source of Sn accumulation in skipjack tuna. On the other hand, relatively low concentrations of BTs were found in the liver of cetaceans from the coastal waters of the Philippines, which ranged 42-98 ng/g wet weight. Significantly lower hepatic BT concentrations in cetaceans in tropical waters were noted compared with those inhabiting temperate waters proximal to developed nations. This result could imply smaller usage of BTs in the Philippines at least at the present.
\end{abstract}

Keywords: Butyltin, Green mussel, TBT

\section{INTRODUCTION}

Over the last two decades, rapid increase of chemical trade in developing countries in Asia was recognized, which implied greater production and usage of toxic chemicals such as heavy metals, organochlorines and butyltins. These activities could lead to increase exposure of humans and wildlife to these chemicals (Tanabe, 1999). Consequently, environmental problems associated with these persistent organic pollutants became a serious concern, particularly in the aquatic environment.
Since the 1960s, BTs have been widely used for maritime structures, aquaculture activities, lumber preservatives and slimicides in cooling system, and as an effective antifouling agent in paints (Sudaryanto et al., 2002). Its derivatives dibutytin (DBT) and monobutyltin (MBT) were mostly used as stabilizers in polyvinyl chloride and as catalysts in the production of polyurethane foams, silicones, and in other industrial processes (Fent, 1996). Widespread usage of butyltins motivated the conduct of numerous studies in order to elucidate environmental contamination and impacts. Considerable studies reported adverse 
effects of BTs on non-target marine organisms, such as shell malformation in oysters (Alzieu and Heral, 1984; Beaumont and Budd, 1984; Bryan and Gibbs, 1991). In view of these investigations, aquatic pollution by BTs has been given much attention in many countries, which eventually led to its restriction, particularly the TBT-based antifouling paints, in most developed nations since the 1980s. However, in most developing Asian countries, including the Philippines, such control is yet to be enforced. In addition, an increasing demand for antifouling paints is expected in the Asia-Pacific region (Layman, 1995). Thus, ecotoxicological studies in this region have started giving considerable attention to the aquatic pollution and toxic biological effects by BTs in this region.

Since 1994, monitoring studies in connection with the Asia-Pacific Mussel Watch Program (APMW), aimed at monitoring the pollution in Asian coastal waters have been conducted. Results presented here form part of the collaborative research project among scientists from ASEAN countries, spearheaded by the APMW Project Leader: Prof. Shinsuke Tanabe of the Center for Marine Environmental Studies (CMES) at Ehime University, Japan. Furthermore, in an effort to extend the conduct of continuous and comprehensive monitoring survey of BTs in the ocean environment, widely distributed and globally migrating organisms such as marine mammals and skipjack tuna were also considered for further investigations by the same group of collaborating scientists from the Asia-Pacific region. As one of the participating scientists in these cooperative research investigations, this paper is presented to elucidate the contamination by BTs in the aquatic environments of the Philippines. Moreover, to determine the degree of contamination in these waters, concentrations of butyltin compounds detected were compared with reported values from other regions.

\section{MATERIALS AND METHODS}

\section{Samples}

Whole soft tissues of green mussels Perna viridis from various coastal sites; liver tissues of marine mammals including Fraser's dolphin Lagenodelphis hosei and spinner dolphin Stenella longirostis from the northeastern part of Sulu Sea; and liver tissues of skipjack tuna collected from the marine waters off the Philippines were considered for the analysis of BTs residues (Fig. 1). Mussel samples were stored in polyethylene bags, kept in a cooler box with dry ice and then

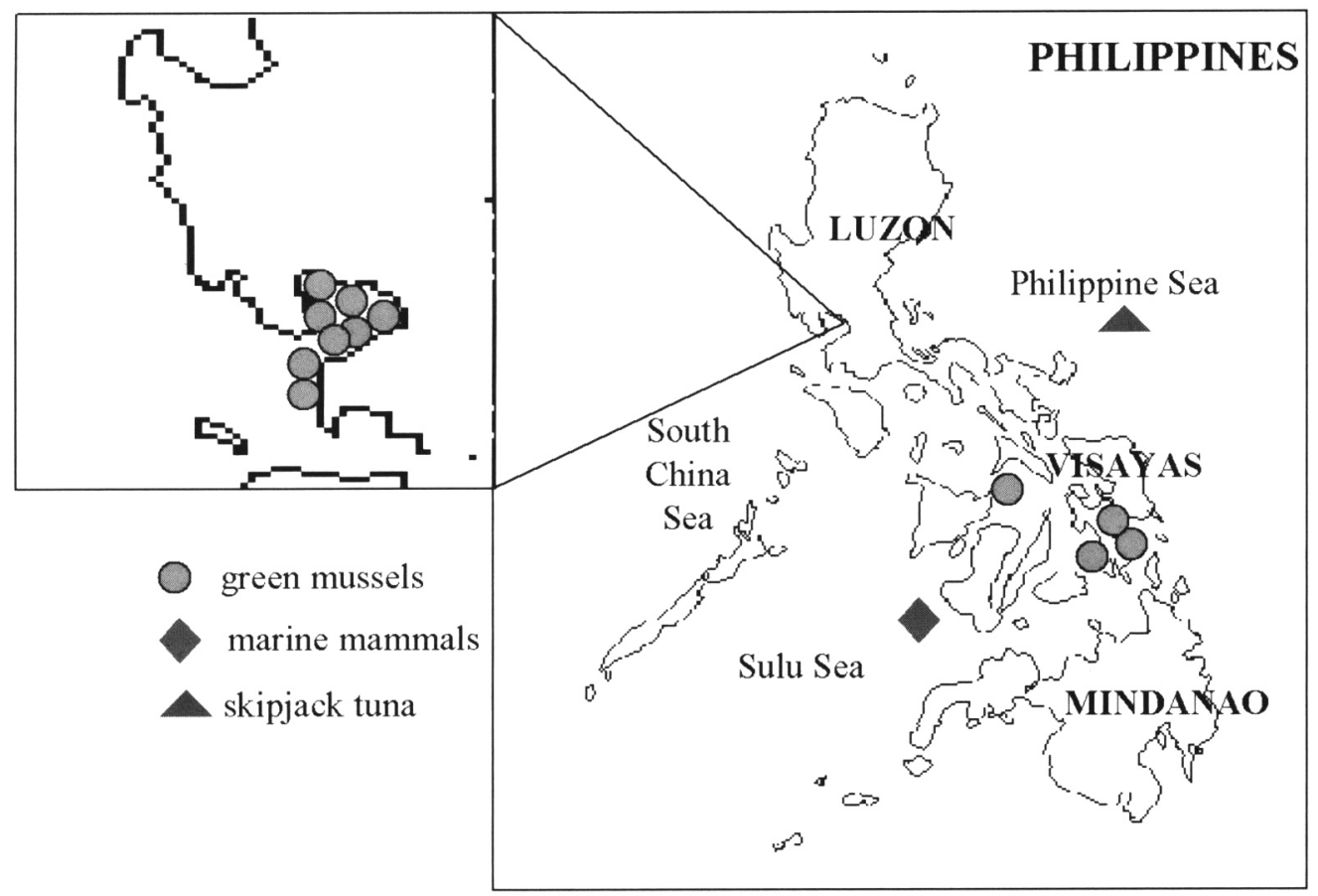

Figure 1. Sites considered for the collection of green mussels, marine mammals and skipjack tuna from the coastal and offshore waters of the Philippines. 
immediately kept in a deep-freezer. The frozen mussels were subsequently transported to the laboratory, biometric data measured (Table 1), thawed, scraped clean and shucked. The whole soft tissues were pooled, homogenized, then kept in clean glass bottles. All samples were frozen at $-20^{\circ} \mathrm{C}$ until chemical analysis. On the other hand, after dissection of the marine mammals and skipjack tuna employed for this study, the liver tissues were likewise stored in polyethylene bags at $-20^{\circ} \mathrm{C}$ until analyses.

\section{Chemical analysis}

For the whole soft tissues of the green mussels: the analytical method of BTs was conducted based on the procedure previously described (Kan-atireklap et al., 1997). Briefly, the method consists of extraction, propylation, purification and quantification by Hewlett-Packard 5890 Series II gas chromatograph equipped with a flame photometric detector (GC-FPD). Recoveries of BTs from the spiked mussel tissues were $87 \pm 14 \%$, $137 \pm 20 \%$ and $107 \pm 25 \%$ for MBT, DBT and TBT $(\mathrm{n}=7)$, respectively. The detection limit was $3 \mathrm{ng}$ $\mathrm{g}^{-1}$ for MBT and $1 \mathrm{ng} \mathrm{g}^{-1}$ for DBT and TBT.

For the liver tissues of the marine mammals and skipjack tuna: the chemical analysis of BTs was conducted following the method previously described (Iwata et al., 1995). Concentrations of BTs are reported as nanograms of cation per gram on a wet weight basis, unless otherwise specified. In addition, concentrations were also calculated on a dry-weight basis based on the moisture contents of the samples. In the case of the skipjack tuna, the analytical procedure for total tin ( $\Sigma \mathrm{Sn}$ ) was based on the method described elsewhere (Le et al., 1999) with a slight modification. Detection limit was $10 \mathrm{ng} \mathrm{Sn/g}$ on a dry weight basis. The recovery of $\mathrm{Sn}$ in this method was checked by analysing a certified material (NIES No. 11), and

Table 1. Biometric data of green mussels collected from coastal waters of the Philippines.

\begin{tabular}{|c|c|c|c|c|}
\hline \multirow{2}{*}{ Location } & \multirow{2}{*}{ Sampling date } & \multirow{2}{*}{$n$} & \multirow{2}{*}{ Shell length (mm) } & Soft tissue weight \\
\hline & & & & (g wet wt) \\
\hline Paranaque, Metro Manila & 941122 & 32 & $40(35-50)$ & $1(0.8-2)$ \\
\hline Ermita, Manila Bay & 941125 & 19 & $47(40-57)$ & $3(2-6)$ \\
\hline Malate, Manila Bay & 941127 & 32 & $54(48-63)$ & $3(1-4)$ \\
\hline Bocaue, Bulacan & 941128 & 41 & $65(51-80)$ & $4(2-8)$ \\
\hline Bacoor, Cavite & 941130 & 39 & $63(54-80)$ & $4(2-6)$ \\
\hline Bocaue, Bulacan & 970411 & 29 & $66(57-80)$ & $8(5-13)$ \\
\hline Bacoor, Cavite & 970409 & 30 & $77(63-109)$ & $12(7-26)$ \\
\hline Jiabong, Samar & 970404 & 30 & $77(48-100)$ & $7(2-11)$ \\
\hline Villareal, Samar & 970405 & 30 & $76(63-86)$ & $8(6-11)$ \\
\hline San Pedro Bay, Leyte & 970406 & 30 & $78(62-114)$ & $5(2-14)$ \\
\hline Sapian Bay, Capiz & 970407 & 18 & $76(69-87)$ & $5(4-7)$ \\
\hline Samal, Bataan & 970408 & 51 & $46(35-53)$ & $3(2-5)$ \\
\hline Malabon, Metro Manila & 970410 & 30 & $68(58-80)$ & $10(5-16)$ \\
\hline Pamarawan, Bulacan & 980326 & 15 & $81(74-93)$ & $8(6-10)$ \\
\hline Obando, Bulacan & 980317 & 82 & $58(17-89)$ & $4(2-10)$ \\
\hline Malabon, Metro Manila & 980316 & 71 & $63(41-87)$ & $6(2-14)$ \\
\hline Bacoor, Cavite & 980327 & 43 & $69(60-77)$ & $7(5-19)$ \\
\hline San Pedro Bay, Leyte & 980321 & 15 & $104(89-117)$ & $17(13-27)$ \\
\hline Jiabong, Samar & 980322 & 46 & $67(50-95)$ & $5(2-13)$ \\
\hline Villareal, Samar & 980323 & 51 & $67(51-84)$ & $4(2-8)$ \\
\hline Sapian Bay, Capiz & 980408 & 87 & $64(41-87)$ & $4(2-10)$ \\
\hline
\end{tabular}


our result $(2.5 \pm 0.1 \mu \mathrm{g} \mathrm{Sn} / \mathrm{g}, \mathrm{n}=4)$ agreed well with the certified value $((2.4 \pm 0.1 \mu \mathrm{g} \mathrm{Sn} / \mathrm{g})$.

\section{RESULTS AND DISCUSSION}

Green mussels. Among the BTs, TBT was detected in most of the sampling sites at relatively high concentrations, whereas the concentrations of DBT and MBT were lower (Table 2). Concentrations of BTs in green mussels collected in 1994-98 ranged from $<2$ to $51 \mathrm{ng} \mathrm{g}^{-1}$ for MBT, $<1$ to $100 \mathrm{ng} \mathrm{g}^{-1}$ for DBT and $<1$ to $640 \mathrm{ng} \mathrm{g}^{-1}$ for TBT. Relatively high TBT concentrations were observed in samples collected from Manila Bay, where maritime activities are quite intensive, considering that is a major shipping traffic area with large harbours. On the other hand, BTs levels were found to be low in green mussels collected from aquaculture areas (ranging from $<1 \mathrm{ng} \mathrm{g}^{-1}$ to $4 \mathrm{ng} \mathrm{g}^{-1}$ ), implying minimal usage of BTs for aquaculture activities in the Philippines. Thus, it is probable that the major BTs pollution sources in the country are far sea or commercial vessels that could be using TBT-coated antifouling agents on the ship hulls. These findings also indicate that BTs contamination seem to be widespread along Philippines' coastal waters (Prudente et al., 1999). TBT levels (ranging $<1$ to $640 \mathrm{ng} \mathrm{g}^{-1}$ ) found in mussel samples from Philippine waters were comparable with those in Thailand, but were higher than those in other Asian countries such as Malaysia and Hongkong (Table 3). Similar to Thailand (Kan-atireklap et al., 1997), pollution of BTs in the Philippines may be considered to be "high" among Asian developing countries so far reported.

The compositional ratio of butyltin derivatives in $P$. viridis analysed was observed to be in the order of TBT $>$ DBT $>$ MBT. Among BTs, TBT was the dominant compound occupying about $70 \%$

Table 2. Concentrations ( $\mathrm{ng} \mathrm{g}^{-1}$ wet weight) of butyltin compounds (BTs) in green mussels collected from Philippine coastal waters.

\begin{tabular}{|l|l|c|c|c|c|}
\hline \multicolumn{1}{|c|}{ Location } & \multicolumn{1}{|c|}{ Area description } & MBT & DBT & TBT & BTs $^{*}$ \\
\hline 1994 & & & & & \\
\hline Paranaque, Metro Manila & Urban area, aquaculture area & 15 & 13 & 76 & 104 \\
\hline Ermita, Manila Bay & Harbor, shipping line, urban area & 47 & 100 & 640 & 787 \\
\hline Malate, Manila Bay & Harbor, shipping line, urban area & 51 & 43 & 200 & 294 \\
\hline Bocaue, Bulacan & Agriculture, aquaculture area & 5 & 4 & 13 & 22 \\
\hline Bacoor, Cavite & Urban area, aquaculture area & 9 & 8 & 34 & 51 \\
\hline Bocaue, Bulacan & Agriculture, aquaculture area & $<3$ & 12 & 34 & 46 \\
\hline 1997 & & & & & \\
\hline Bacoor, Cavite & Urban area, aquaculture area & $<3$ & 16 & 43 & 59 \\
\hline Jiabong, Samar & Agriculture, aquaculture area & $<3$ & 3 & 1 & 4 \\
\hline Villareal, Samar & Agriculture, aquaculture area & $<3$ & 2 & 28 & 30 \\
\hline San Pedro Bay, Leyte & Agriculture, aquaculture area & $<3$ & $<1$ & $<1$ & $<1$ \\
\hline Sapian Bay, Capiz & Agriculture, aquaculture area & $<3$ & 1 & $<1$ & 1 \\
\hline Samal, Bataan & Agriculture, aquaculture area & $<3$ & $<1$ & $<1$ & $<1$ \\
\hline Malabon, Metro Manila & Urban area, aquaculture area & 3 & 15 & 44 & 62 \\
\hline 1998 & & & & & \\
\hline Pamarawan, Bulacan & Agriculture, aquaculture area & $<2.0$ & 2.1 & 1.7 & 3.8 \\
\hline Obando, Bulacan & Agriculture, aquaculture area & 7.7 & 5.8 & 3.9 & 17 \\
\hline Malabon, Metro Manila & Urban area, aquaculture area & 8.1 & 19 & 47 & 74 \\
\hline Bacoor, Cavite & Urban area, aquaculture area & 15 & 18 & 31 & 64 \\
\hline San Pedro Bay, Leyte & Agriculture, aquaculture area & 4.7 & 2.8 & 9.8 & 17 \\
\hline Jiabong, Samar & Agriculture, aquaculture area & $<2.0$ & $<1.3$ & 0.8 & 0.8 \\
\hline Villareal, Samar & Agriculture, aquaculture area & $<2.0$ & $<1.3$ & 0.8 & 0.8 \\
\hline Sapian Bay, Capiz & Agriculture, Aquaculture area & 2.1 & 1.6 & 3 & 6.7 \\
\hline *BTs=MBT+DBT+TBT & & & & & \\
\hline & & & & \\
\hline
\end{tabular}


Table 3. Range concentrations (ng g ${ }^{-1}$ wet wt) of MBT, DBT and TBT residues in bivalve molluscs collected worldwide and reported in the literature.

\begin{tabular}{|c|c|c|c|c|c|}
\hline Species & Location (year surveyed) & MBT & DBT & TBT & Reference \\
\hline \multirow[t]{6}{*}{ Mytilus edulis } & East Coast, USA (1989-1990) & ND-28 & $2-116$ & $2-240$ & Short and Sharp, 1989 \\
\hline & West Coast, USA (1989-1990) & ND-60 & $2-148$ & $2-276$ & Short and Sharp, 1989 \\
\hline & Tokyo Bay, Japan (1989) & $20-120$ & $40-450$ & $20-240$ & Higashiyama et al. , 1991 \\
\hline & British Columbia, Canada (1995) & $2.4-15$ & $2.7-31$ & $25-153$ & Stewart and Thompson, 1994 \\
\hline & Coastal Harbor, Canada (1995) & ND-210 & ND-416 & $10-585$ & Chau et al. , 1997 \\
\hline & South and East Coasts, Korea (1997-1999) & $9.3-300$ & $19-1100$ & $17-1200$ & Hong et al. , 2002 \\
\hline \multirow[t]{2}{*}{ Mytilus galloprovincialis } & West Coast, Portugal (1986) & $3.2-169$ & ND-82 & ND-114 & Quevauviller et al. , 1989 \\
\hline & Western Mediterranean (1996) & $10-204$ & $4-1094$ & $1-1151$ & Morcillo and Porte, 1998 \\
\hline \multirow[t]{10}{*}{ Perna viridis } & Thailand (1994-1995) & $<3-45$ & $<2-80$ & $3-680$ & Kan-atireklap et al., 1997 \\
\hline & India (1994-1995) & $<3-250$ & $<1-110$ & $<1-150$ & Kan-atireklap et al., 1998 \\
\hline & India (1998) & $<2.2-66$ & $<0.86-150$ & $0.83-570$ & Sudaryanto et al. , 2002 \\
\hline & Indonesia (1998) & $1.5-13$ & $<0.58-14$ & $2.2-38$ & Sudaryanto et al. , 2002 \\
\hline & Malaysia (1998) & $<2.6-74$ & $<1.0-160$ & $3.5-730$ & Sudaryanto et al. , 2002 \\
\hline & Cambodia (1998) & $<2-25$ & $<0.98-37$ & $2.4-88$ & Sudaryanto et al. , 2002 \\
\hline & Vietnam (1998) & $<2.1-3.3$ & $<0.86-19$ & $2.1-64$ & Sudaryanto et al. , 2002 \\
\hline & Hongkong (1999) & $4.2-90$ & 4.9-76 & $16-330$ & Sudaryanto et al. , 2002 \\
\hline & Philippines (1994-1997) & $<3-51$ & $<1-100$ & $<1-640$ & Prudente et al ., 1999 \\
\hline & Philippines (1997-1998) & $<2.0-15$ & $<1.3-19$ & $0.8-47$ & Sudaryanto et al. , 2002 \\
\hline
\end{tabular}

in most locations, while DBT and MBT comprised less than $30 \%$. These findings conform with the observations made by Kan-atireklap et al. (1997) on the limited ability of $P$. viridis to metabolize TBT to DBT and MBT similar to other molluscs. Additionally, continuous input of TBT in the coastal waters of the Philippines may also provide a plausible explanation for the higher ratio of TBT found in mussel samples analysed. It is interesting to note however, that mussels from rural areas contained TBT at lower concentrations and proportions, indicating that TBT usage as antifouling agents in these rural areas seems to be minimal.

Since mussels are one of the commonly consumed seafood items in the country, it is worthwhile to assess possible risk to human health. In an earlier study conducted by Sudaryanto et al. (2002), it was pointed out that to assess risk to human health from the consumption of seafood products, tolerable average residue levels (TARLs) as suggested by Belfroid et al. (2000) could be calculated. Using the data of average seafood consumption reported by Food and

Table 4. Concentrations ( $\mathrm{ng} \mathrm{g}^{-1}$ wet weight) of butyltins in the liver of cetaceans from Sulu Sea, the Philippine

\begin{tabular}{|l|c|c|c|c|c|c|c|}
\hline \multirow{2}{*}{ Species } & WBL $^{*}$ & \multicolumn{2}{|c|}{$\mathbf{N}$} & \multirow{2}{*}{ MBT } & \multirow{2}{*}{ DBT } & TBT & \multirow{2}{*}{ BTs } \\
\cline { 2 - 8 } & $\mathbf{( c m})$ & $\mathbf{M}$ & $\mathbf{F}$ & & & & \\
\hline & & & & & $\mathbf{5 3}$ & $\mathbf{2 6}$ & $\mathbf{9 4}$ \\
\hline Lagenodelphis hosei & $221-225$ & 1 & 1 & $\mathbf{1 5}$ & $(38-68)$ & $(21-31)$ & $(89-98)$ \\
\hline Fraser's dolphin & & & & $(<4.0-29)$ & & & $\mathbf{2 1}$ \\
\hline & & & & & & & $\mathbf{3 5}$ \\
\hline Stenella longirostris & $182-192$ & 1 & 1 & $\mathbf{2}$ & $(23-41)$ & $(19-23)$ & $(42-67)$ \\
\hline Spinner dolphin & & & & $(<4.0-3.1)$ & & & \\
\hline
\end{tabular}

*WBL: Whole body length (cm); N:no.of samples.

$\mathrm{BTs}=\mathrm{MBT}+\mathrm{DBT}+\mathrm{TBT}$

Bold:mean concentration. Ranges are given in parentheses. 
Agriculture Organization (FAO) of the United Nations, TARL for seafood in the Philippines was estimated at $173 \mathrm{ng} \mathrm{g}^{-1}$ wet weight for an average person weighing $60 \mathrm{~kg}$ (Sudaryanto et al., 2002). Concentrations of TBT or the sum of TBT and DBT (TBT + DBT) in some of the mussels analysed were found to have exceeded this value, which could be suggestive that people consuming seafood from areas with high butyltin contamination may be at risk from elevated exposure to BTs. Moreover, Sudaryanto et al. (2002) evaluated the extent of anthropogenic input of tin by determining the residues of total tin $(\Sigma \mathrm{Sn}$ : organic $\mathrm{Sn}+$ inorganic $\mathrm{Sn}$ ) against the BTs residues found in green mussels and reported that the ratio of BTs in $\Sigma \mathrm{Sn}$ were higher in the coastal areas where high boating activities were occurring. These observations indicate that anthropogenic sources contribute considerably in tin accumulation in green mussels and that most of the total tin in mussels exists in organic form such as BTs, which further imply that tin compounds originated mostly from anthropogenic sources.

Marine mammals. Relatively low concentrations of BTs were measured in the liver of cetaceans from the Sulu Sea, which ranged at 42-98 $\mathrm{ng} \mathrm{g}^{-1}$, wet wt. (Table 4). These findings were similar to the low BTs residues (ranging $<1$ $30 \mathrm{ng} \mathrm{g}^{-1}$ wet wt.) found in green mussels from the waters in the Visayas region, which is proximal to the site where these marine mammals were collected. BTs residue levels in these cetaceans compare favorably with those found in cetaceans collected from China (350 to $1200 \mathrm{ng} \mathrm{g}^{-1}$, wet wt), another developing country in Asia (Tanabe et al., 1998). Further, it has been reported that cetaceans inhabiting waters adjacent to developing countries in the tropics and subtropics including the Philippines and India contain significantly lower hepatic BT concentrations compared with those inhabiting temperate waters proximal to developed nations such as Japan (Tanabe et al., 1998). This could be indicative of significant and continuous inputs of BTs in the coastal waters of these developed countries, while smaller usage in developing countries, such as the Philippines, is implied at least at present.

Among the BTs, DBT was predominant in most of the liver samples of these marine mammals, followed by TBT and MBT. This pattern is similar to BTs composition observed in other cetaceans previously studied, which includes harbour porpoises from the Black Sea (Madhusree et al., 1997), bottle-nosed dolphins along the coasts of Italy (Kannan et al., 1996), and stranded cetaceans along the U.S. Atlantic and Gulf coasts (Kannan et al., 1997). These findings are indicative of similar metabolic processes among cetaceans. Interestingly, higher accumulations of DBT/BTs than TBT/BTs were detected in spinner and dolphins collected from the the Sulu Sea, Philippines. In contrast, the same species of spinner dolphins collected from Bay of Bengal, India revealed higher ratio of TBT/BTs

Table 5. Mean and range of butyltins and total tin concentrations green mussels and skipjack tunas collected from Philippine waters.

\begin{tabular}{|c|c|c|c|c|c|c|c|c|c|}
\hline Species & Location & MBT $^{*}$ & DBT $^{*}$ & TBT $^{*}$ & BTs $^{*}$ & TBT / BTs (\%) & SBTs $^{* *}$ & SSn $^{* *}$ & SBTs / SSn (\%) $^{*}$ \\
\hline & & & & & & & & & \\
\hline green mussels & urban coastal waters & 7.9 & 11 & 21 & 40 & 45 & 89 & 130 & 63 \\
\hline & & $(<2.0-15)$ & $(2.1-19)$ & $(1.7-47)$ & $(3.8-74)$ & $(23-64)$ & $(9.6-150)$ & $(28-180)$ & $(28-107)$ \\
\hline & & & & & & & & & \\
\hline green mussels & rural coastal waters & 2.2 & 1.7 & 3.6 & 6.3 & 76 & 17 & 47 & 26 \\
\hline & & $(<2.0-4.7)$ & $(<1.3-2.8)$ & () $.8-3)$ & $(0.8-17)$ & $(45-100)$ & $(1.6-74)$ & $(17-74)$ & $(4.2-64)$ \\
\hline & & & & & & & & & \\
\hline skipjack tuna & offshore waters & 1.9 & 35 & 150 & 180 & 80 & 220 & 230 & 88 \\
\hline & & $(<1.8-5.7)$ & $(16-66)$ & $(62-200)$ & $(78-270)$ & $(75-86)$ & $(95-310)$ & $140-320$ & $(68-100)$ \\
\hline
\end{tabular}

Bold:mean concentration; ranges are given in parentheses.

$*_{\text {ng/g wet wt }}$

**ng Sn/g dry wt 
than DBT/BTs (Tanabe et al., 1998). The reason for the apparent difference in BTs composition among the spinner dolphins collected from India and the Philippines remains unclear. However, higher maritime activities in the Bay of Bengal than in Sulu Sea could be a plausible explanation.

Skipjack Tuna. Mean and range concentrations of BTs and $\Sigma \mathrm{Sn}$ in the liver of skipjack tunas collected from offshore waters of the Philippines and the green mussels from various coastal waters is shown in Table 5. Concentrations of BTs in the liver tissues of skipjack tuna collected off Philippine waters in December 1997 ranged at $78-270 \mathrm{ng} / \mathrm{g}$ wet weight. Among BTs, TBT was detected at relatively higher concentrations, whereas DBT and MBT were lower. This pattern conforms to those observed in green mussels, which indicate continuous inputs of TBT into the aquatic environment and the presence of recent sources in the offshore waters.

Similar to the pattern observed in green mussels, high percentage of BTs in total tin $(\Sigma \mathrm{Sn}$ : inorganic tin + organic tin) were found in the liver tissues of the tunas, suggestive that anthropogenic BTs represent the major source of Sn accumulation in skipjack tuna. As reported by Ueno et al. (2004), BTs occupied higher percentages in $\Sigma$ Sn concentrations in skipjack tuna collected from offshore waters around Asian developing countries having high concentrations of BTs, which suggested that hepatic Sn exists primarily in organic form as BTs that originate from anthropogenic sources.

\section{CONCLUSION}

Significant butyltin concentrations in green mussels collected from the coastal areas of the Philippines revealed contamination along nearshore marine waters. Relatively high BTs concentrations were observed in green mussels collected from areas with intensive maritime activities, suggestive that antifouling paints could be the major TBT source. While low TBT levels found in green mussels from aquaculture areas imply minimal usage of BTs for aquaculture activities. Similarly BTs residues found in skipjack tuna collected from offshore waters of the Philippines indicated BTs contamination and presence of recent butyltin pollution sources. High percentages of BTs in $\Sigma \mathrm{Sn}$ found in the liver of the skipjack tuna suggest anthropogenic BTs as major source of tin accumulation in these animals. While the considerable BTs levels found in the liver tissues of marine mammals collected from Sulu Sea, Philippines imply that BTs accumulate at measurable levels in the liver of higher trophic marine animals. Considering the unregulated usage of TBT and the possible increasing demand for TBT-containing paints in the Philippines, contamination by BTs in its aquatic environments may become serious in the future. It is therefore necessary to conduct continuous monitoring in order to make appropriate decisions on the future issues of butyltin contamination in the aquatic environments.

Acknowledgments. The author extends her heartfelt gratitude to Prof. Shinsuke Tanabe of the Center for Marine and Environmental Studies (CMES) of Ehime University for providing the inspiration and technical assistance in the monitoring of persistent organic pollutants in the Philippines. Sincere appreciation is likewise accorded to the scientists and staff of CMES for their help in the chemical analyses. This study was supported partly by a grant-in-aid for research from the Japan Society for the Promotion of Science.

\section{REFERENCES}

Alzieu, C., and M. Heral. 1984. Ecotoxicological effects of organotin compounds on oyster culture. In: "Ecotoxicological Testing for the Marine Environment". vol. 2. Persoone, G., Jaspers, E. and Claus, C. (eds.), pp. 187-195, State University, Belgium.

Beaumont, A.R., and M.D. Budd. 1984. High mortality of the larvae of the common mussel at low concentrations of tributyltin. Marine Pollution Bulletin, 15: 402-405.

Belfroid, A.C., M. Purperhart, and F. Ariese. 2000. Organotin levels in seafood. Marine Pollution Bulletin, 40: 226-232.

Bryan, G.W., and P.E. Gibbs. 1991. Impact of low concentrations of tributyltin (TBT) on marine organisms: a review. In: "Metal Ecotoxicology Concepts and Applications". Newman, M.C. and Mc Intosh, A.W. (eds.), pp. 323-361, Lewis Publishers, New York.

Chau, Y.K., R.J. Maguire, M. Brown, F.m.Yang, S.P. Batchelor, and J.A.J. Thompson. 1997. Occurrence of butyltin compounds in mussels from Canada. Applied Organometallic Chemistry, 11: 903-912. 
Fent, K. 1996. Ecotoxicology of organotin compounds. Critical Reviews of Toxicology, 26: 1-117.

Higashiyama, T., H. Shiraishi, A. Otsuki, and S. Hashimoto. 1991. Concentrations of organotin compounds in blue mussels from the wharves of Tokyo Bay. Marine Pollution Bulletin, 22: 585-587.

Hong, H.K., S. Takahashi, B.Y. Min, and S. Tanabe. 2002. Butyltin residues in blue mussels Mytilus edulis and arkshells Scapharca broughtonii collected from Korean coastal waters. Environmental Pollution, 117: 475-498.

Iwata, H., S. Tanabe, T. Mizuno, and R. Tatsukawa. 1995. High accumulation of toxic butyltins in marine mammals from Japanese coastal waters. Environmental Science and Technology, 29: 29592962.

Kan-atireklap, S., J. Sanguansin, M. Tabucanon, and M. Hungspreugs. 1997. Contamination by butyltin compounds and organochlorine residues in green mussel (Perna viridis, L.) from Thailand coastal waters. Environmental Pollution, 97: 79-89.

Kan-atireklap, S., N.T.H. Yen, S.Tanabe, and AN. Subramanian, 1998. Butyltin compounds and organochlorine residues in green mussel Perna viridis from India. Toxicological Environmental Chemistry, 67: 409-424.

Kannan, K., S. Corsolini, S. Focardi, S. Tanabe, and R. Tatsukawa. 1996. Accumulation pattern of of butyltin compounds in dolphin, tuna, and shark collected from Italian coastal waters. Archives of Environmental Contamination and Toxicology, 31: 19-23.

Kannan, K., K. Senthilkumar, B.G. Loganathan, S. Takahashi, D.K. Odell, and S. Tanabe. 1997. Elevated accumulation of tributyltin and its breakdown products in bottlenose dolphins Tursiops truncates found stranded along the US Atlantic and Gulf coasts. Environmental Science and Technology, 31:296-301.

Layman, P.L. 1995. Marine coatings industry adopts new technology for shifting markets. Chemical Engineering News.

Le, L.T.H., S. Takahashi, K. Saeki, S. Tanabe, N. Nakatani, N. Miyazaki, and Y. Fujise. 1999. High percentage of butyltin residues in total tin in the livers of cetaceans from Japanese coastal waters. Environmental Science and Technology, 33:17811786.
Madhusree, B., S. Tanabe, A.O. Amaha, R. Tatsukawa, N. Miyazaki, E. Ozdamar, O. Aral, O. Samsun, and B. Ozturk. 1997. Contamination by butyltin compounds in harbour porpoise Phocoena phocoena from the Black Sea. Frezen Journal of Analytical Chemistry, 359: 244-248.

Morcillo, Y., and C. Porte. 1998. Monitoring of organotin compounds and their effects in marine molluscs. Analytical Chemistry, 17: 109-116.

Prudente, M., H. Ichihashi, S. Kan-atireklap, I. Watanabe, and S. Tanabe. 1999. Butyltins, organochlorines and metal levels in green mussel Perna viridis $L$. from the coastal waters of the Philippines. Fisheries Science, 65: 441-447.

Quevauviller, P., R. Lavigne, R. Pinel, and M. Astruc, M. 1989. Organotins in sediments and mussels from the Sado estuarine system (Portugal). Environmental Pollution, 57:149-166.

Short, J.W., and J.L. Sharp. 1989. Tributyltin in bay mussels Mytilus edulis of the Pacific Coast of the United States. Environmental Science and Technology, 23: 740-743.

Stewart, C., and J. Thompson. 1994. Extensive butyltin contamination in Southwestern Coastal British Columbia, Canada. Marine Pollution Bulletin, 28: 601-606.

Sudaryanto, A., S. Takahashi, I. Monirith, A. Ishmail, M. Muchtar, J. Zheng, B. Richardson, A. Subramanian, M. Prudente, N. Duc Hue, and S. Tanabe. 2002. Asia-Pacific Mussel Watch: Monitoring of Butyltin Contamination in Coastal Waters of Asian Developing Countries. Environmental Toxicology and Chemistry, 21(10) pp. 2119-2130.

Tanabe, S., M. Prudente, T. Mizuno, J. Hasegawa, H. Iwata, and N. Miyazaki. 1998. Butyltin contamination in marine mammals from North pacific and Asian coastal waters. Environmental Science and Technology, 32: 193-198.

Tanabe, S. 1999. Butyltin Contamination in Marine Mammals - A Review. Marine Pollution Bulletin, 39:1-12, pp.62-72.

Ueno, D., S. Inoue, S. Takahashi, K. Ikeda, H. Tanaka, A. Subramanian, G. Fillmann, P.K. Lam, J. Zheng, M. Muchtar, M. Prudente, K. Chung, and Tanabe, S. 2004. Global pollution monitoring of butyltin compounds using skipjack tuna as a bioindicator. Environmental Pollution, 127: 1-12. 